\title{
表面科学としてのシリセンの面白さ： 実験・理論の現状と今後の展望
}

\author{
江 澤 雅 彦 \\ 東京大学大学院工学系研究科物理工学専攻 囸 113-8656 東京都文京区本郷 7 丁目 3-1 \\ (2014 年 1 月 15 日受付；2014 年 4 月 9 日掲載決定) \\ Attractive Features of Silicene as a Surface Science : \\ Experimental and Theoretical Perspectives and Future Problems \\ Motohiko Ezawa \\ Department of Applied Physics, University of Tokyo, 7-3-1 Hongo, Bunkyo-ku, Tokyo 113-8656 \\ (Received January 15, 2014 ; Accepted April 9, 2014)

\begin{abstract}
We review the recent progress of the study of silicene, which is a honeycomb structure of silicon atoms. Silicene shares many similar properties with graphene but has some extra exciting properties since it is a topological insulator due to its spin-orbit interactions. Silicene has so far been synthesized only on a substrate. The synthesis and the measuring physical properties of silicene are interesting playgrounds of the surface science.
\end{abstract}

KEYWORDS : silicene, topological insulator, quantum spin-Hall effects, graphene, Dirac fermions

\section{1.は じめに}

シリセン（silicene）という物質が基板上に合成され， 大変興味を持たれている。これはシリコンがハニカム格 子状に整列した物質である。炭素がハニカム状に整列し た物質がグラフェン (graphene) なので, シリコンでで きたグラフェンと考えることもできる。この類似性から シリセンはグラフェンと多くの共通性を持っている。実 際, 低エネルギー励起はディラック理論で記述される。 その構造は平坦な構造を持っているグラフェンとは違 い, 座屈 (buckle) している (Fig. 1 参照)。シリセンは 比較的大きなスピン軌道相互作用を持つため, グラフェ ンにはないトポロジカル物性を持っている。このため, グラフェンとトポロジカル絶縁体という最近の物性の合 流点に位置し, 豊富な物理が期待できる物質である。ま た，シリコンでできていることから，従来のシリコン・ デバイスとも相性が良いことが期待される。将来的には シリセンを用いたトポロジカル・デバイスが実現する日

E-mail : ezawa@ap.t.u-tokyo.ac.jp
がくるかもしれない。

シリセンの研究に関しては理論実験ともに日本が先行 している。シリコン・デバイスなどの実績も豊富なの で, 今後とも, 日本でシリセン研究をリードし続けられ ると良い。

シリセンに関しては既に解説記事があるので, そちら

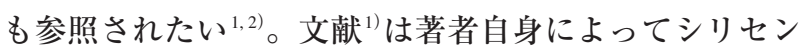

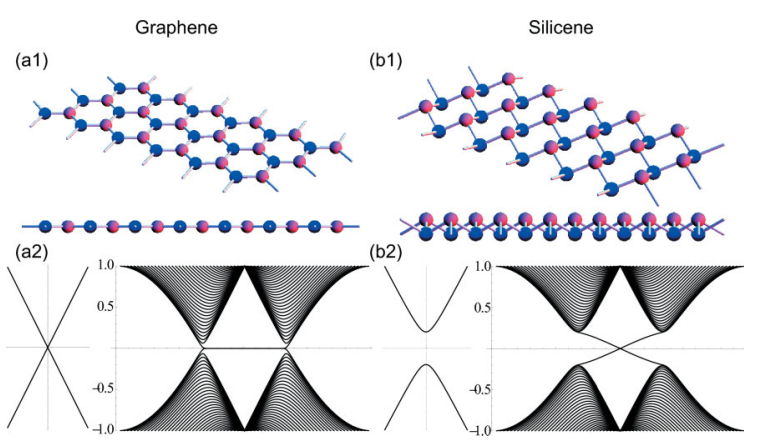

Fig. 1. (color online). Illustrations of (a1) graphene and (b1) silicene. Band structures of (a2) graphene and (b2) silicene. 
の理論について記述されている。このため，本稿では害 験的な側面や今後の展望を中心に記述したいと思う。文 献2)では二ホウ化ジルコニウム上のシリセンの合成に関 して解説がなされている。物性におけるディラック電子 に関しては文献) に特集がある。シリセンはトポロジカ ル絶縁体でもある。トポロジカル絶縁体に関しては文 献 4〜)を参照されたい。さらにシリセンはグラフェンと も多くの共通の性質を持っている。グラフェンに関して は文献》をあげる。

\section{2. シリセンの歴史}

シリセンは 1994 年に第一原理計算によって構造安定 性とディラック・コーンの存在が予言された ${ }^{8)}$ 。本格的 な実験的合成の報告は三つの実験グループにより, 独立 に 2012 年に報告された。フランスの Guy Le Lay のグル ープは銀基板上での走查トンネル顕微鏡（STM 像）と 角度分解光電子分光 (ARPES) の解析から, シリセン が銀基板上で，合成されたことを報告した ${ }^{9}$ （Fig. 2)。 また，東大新領域の川合・高木グループも銀基板上での シリセンの構造が二種類あることを STM 像と LEED (Low Energy Electron Diffraction) で確認した ${ }^{10}$ 。さら に, 北陸先端大の高村グループは二ホウ化ジルコニウム （ZrB2）上でのシリセンの合成を STM 像と ARPES で確 認した ${ }^{11}$ 。また，イリジウム上でもシリセンの合成の報 告がなされている12)。

\section{3. シリセンと表面科学}

シリセンは表面科学と密接な関係がある。まず，シリ センの構造安定性は第一原理計算で確認されているが, シリセンは自然界には存在しない。これはシリセンが大 変反応しやすくすぐ酸化されてしまい, シリカになって しまうからである。グラフェンはグラファイトが自然に 存在するので, グラファイトを引きはがすことで, グラ
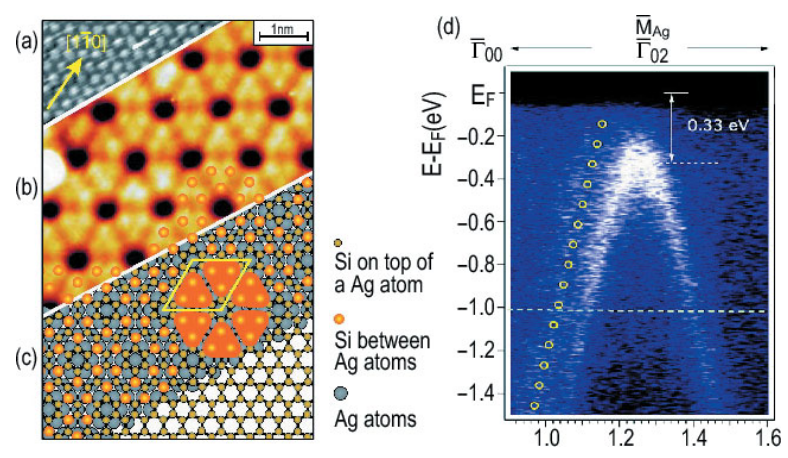

Fig. 2. (color online). (a), (b) and (c) STM and (d) ARPES images of silicene on Ag substrate. See the details in Refs. 9) and 22), from which these figures are taken.
フェンを得ることができる。2010 年のノーベル賞がグ ラフェンに対して与えられたのは記憶に新しい。一層グ ラフェンが鉛筆の芯をスコッチ・テープで剥離するだけ で得られた。一方，グラファイトに対応するシリセンの 積層構造は構造不安定で自然界に存在しない。これはシ リセンが積層した構造はダイヤモンド構造のシリコンの 方が構造安定なため, 構造転移を起こしてしまうためで ある。このため, シリセンを合成するためには基板表面 を使う必要がある。シリセンの実験は超高真空中で高度 な技術で清浄な表面を作製可能な実験グループの独壇場 になっている。

表面の状態を見るとバルクのトポロジカルな性質がわ かるという原理がある。これはトポロジカル絶縁体の分 野では,「バルク・エッジ対応」と呼ばれている。これ は一言で言うと量子スピンホール効果などのトポロジカ ル絶縁体の表面にはヘリカルエッジ状態などの固有のエ ッジ状態が現れる。エッジ状態を観測すると, 系がトポ ロジカルであることか否かがわかる。この観点からも表 面の研究が重要であることがわかる。

シリセンの構造：Fig. 1 に見るように, グラフェンは 完全にフラットな構造をしている。これは炭素が $\mathrm{sp}^{2}$ 軌 道を構成しているからである。一方, シリコンの $\mathrm{sp}^{2}$ 軌 道と $\mathrm{sp}^{3}$ 軌道が混成しているため, シリセンはバックル した構造をしている。シリコンの三次元構造はダイアモ ンド構造にほかならず, $\mathrm{sp}^{3}$ 軌道のみで構成されている。 このため, シリセンの構造は一層のダイアモンド構造で あり, ダイアモンド構造とハニカム構造の中間的性質を 持っている。このグラフェンとシリセンの構造の違いは $\mathrm{s}$ 軌道と $\mathrm{p}$ 軌道のエネルギーの差が炭素の方がシリコン より大きいためである。シリセンのバックルした構造や シリコンが炭素より重いことの帰結としてスピン軌道相 互作用が $3.9 \mathrm{meV}$ あり ${ }^{13,14)}$, トポロジカル絶縁体が実現 している。グラフェンのスピン軌道相互作用は $\mu \mathrm{eV}$ の オーダーなので ${ }^{15,16)}$, シリセンのスピン軌道相互作用は グラフェンの千倍ある。

シリセンとディラック電子 : グラフェンの低エネルギ 一励起はディラック理論で記述される。一般的にハニカ 厶格子の低エネルギー励起はディラック理論で記述され る。グラフェンはギャップのない線形分散を持つのに対 し, シリセンはスピン軌道相互作用によるギャップのあ るディラック分散を持つ。外場を含むシリセン系は, 運 動量 $\left(\hbar k_{x}, \hbar k_{y}\right)$ とフェルミ速度 $\nu_{\mathrm{F}}$ を用いて 2 行 2 列の ディラック方程式で記述できる。

$$
H_{\eta}=\left(\begin{array}{cc}
\Delta_{s_{z}}^{n} & \hbar \nu_{\mathrm{F}}\left(\eta k_{x}-i k_{y}\right) \\
\hbar \nu_{\mathrm{F}}\left(\eta k_{x}-i k_{y}\right) & -\Delta_{s_{z}}^{\eta}
\end{array}\right)
$$


対角成分に現れる量 $\Delta_{s_{z}}^{\eta}$ はディラック電子の質量であ る。これは簡単に対角化できて, 分散関係は

$$
E(k)= \pm \sqrt{\left(\hbar \nu_{\mathrm{F}}\right)^{2} k^{2}+\left(\Delta_{s_{z}}^{\eta}\right)^{2}}
$$

と求まる。ディラック・コーンは決まったスピン指数 $\left(s_{z}= \pm 1\right)$ とバレー指数 $(\eta= \pm 1)$ を持ち, そのギャップ は $2\left|\Delta_{s_{z}}^{\eta}\right|$ である。

シリセンが特に面白いのは電場 $E_{z}$ をシリセンに垂直 にかけることでディラック質量を制御できること ${ }^{17)}$ であ る。これはシリセン特有のバックル構造に起因する。シ リセンは $\mathrm{AB}$ 副格子で形成されているが, $\mathrm{A}$ サイトと $\mathrm{B}$ サイトの高さが違う。このため, 電場を垂直にかけると $\mathrm{A}$ サイトと $\mathrm{B}$ サイトの間に静電ポテンシャルが発生す る。これがディラック電子の質量に寄与する。実際, $\lambda_{\text {so }}$ をスピン軌道相互作用の大きさとして, 質量は $\Delta_{s_{z}}^{\eta}=\eta s_{z} \lambda_{\mathrm{so}}-\ell E_{z}$ となる。電場を大きくしていくと, 臨 界電場でギャップが閉じ, ディラック質量の符号が反転 して, 量子スピンホール相から自明な相へとトポロジカ ル相転移する ${ }^{1)}($ Fig. 3)。

シリセンには電磁波 ${ }^{18)}\left(\lambda_{\Omega}\right)$ の照射や反強磁性秩序 ${ }^{19)}$ $(\Delta M)$ の導入ができ, ディラック質量は

$$
\Delta_{s_{z}}^{n}=\eta s_{z} \lambda_{\mathrm{so}}-\ell E_{z}+\eta \lambda_{\Omega}+s_{z} \Delta M
$$

となる。スピン指数とバレー指数の選び方で, 4 通りの 符号の選び方があるので, 四つのトポロジカル量子数が 存在することになる。これらは, チャーン数, スピン・ チャーン数, バレー・チャーン数, スピン・バレー・チ ヤーン数と呼ばれる。これらは上記の四つの質量を制御 することで完全に制御できる。これはスピンとバレーを

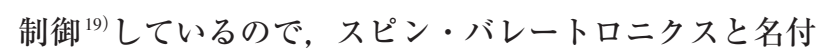
けた。

\section{1 シリセンと量子スピンホール効果}

シリセンはグラフェンよりスピン軌道相互作用が大き く, この結果, 量子スピンホール状態になることが第一 原理計算によって示された ${ }^{13)}$ 。また, 低エネルギー励起

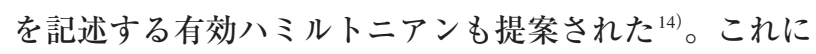

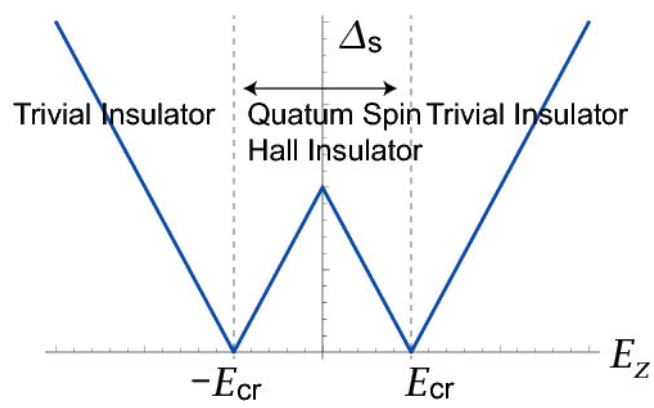

Fig. 3. (color online). Band gap as a function of an external field.
よって, シリセンにおいてトポロジカル物性を議論する ことが可能になった。そもそも量子スピンホール効果は グラフェンで提案されたが, あまりにもスピン軌道相互 作用が小さすぎて現実的ではなかった。その後, HgTe/ $\mathrm{CdTe}$ の量子井戸で量子スピンホール効果は実験的に検 証された。しかし, 水銀とカドミウムは毒性が強く, 実 験が困難であるために, その後の研究は活発ではない。 また, 三次元トポロジカル絶縁体を実現する物質は数多 く見つかっているが, 二次元トポロジカル絶縁体の実現 例はまだほとんどない。この観点から, シリセンがトポ ロジカル絶縁体であることを実験的に確認できれば大変 大きいインパクトがある。

ジグザグ・エッジとアームチェア・エッジ：ハニカム 格子のエッジにはジグザグ・エッジとアームチェア・エ ッジがある。まず, グラフェン・ナノリボンではジグザ グ・エッジには平坦バンドがあり, エッジに局在した波 動関数が存在する。しかし, アームチェア・エッジには そのような状態はない。一方, シリセンはトポロジカル 絶縁体なので, ジグザグとアームチェアにかかわらずに エッジに局在した波動関数が存在する。ジグザグ・エッ ジの $k=\pi / a$ での波動関数の進入長がスピン軌道相互作 用によらずにほとんど一原子であるのに対して，アーム チェア・エッジでは進入長はスピン軌道相互作用の大き さに反比例する ${ }^{20)}$ 。

シリセンがトポロジカル絶縁体であることを確認でき るか：前述したように系がトポロジカル絶縁体であるこ とを確認するためにはエッジ状態を見るのが一番手っ取 り早い。二次元トポロジカル絶縁体のエッジ状態の存在 を実験的に確認するためには STM で局所状態密度を測 定し，エッジにピークを確認する方法と ARPES でエッ ジ状態のギャップレスモードを直接観測する方法があ る。通常の ARPES では三次元トポロジカル絶縁体の表 面状態は観測できるが, 二次元トポロジカル絶縁体の表 面状態は一次元になってしまい強度がきわめて小さくま だ観測に成功した例はない。しかし, ARPES の強度を 上げたり，精度を上げていくことで片鱗は見え始めてい る。さらに光電子顕微鏡 (PEEM) や nano-ARPES のよ うに nm スケールの空間分解能を有する ARPES や自由 電子レーザー（FEL）など非常に強い輝度の光を用いた ARPES ができれば，二次元トポロジカル絶縁体のエッ ジ状態も見える時代が来るかもしれない。グラフェンで はジグザグ・エッジのときには, エッジにするどいピー クがたつことが知られている。このため, シリセンのジ グザグ・エッジに局所状態密度のピークを観測しても, それがすぐにシリセンがトポロジカル絶縁体であること の証拠にはならない。一方, グラフェンのアームチェ 

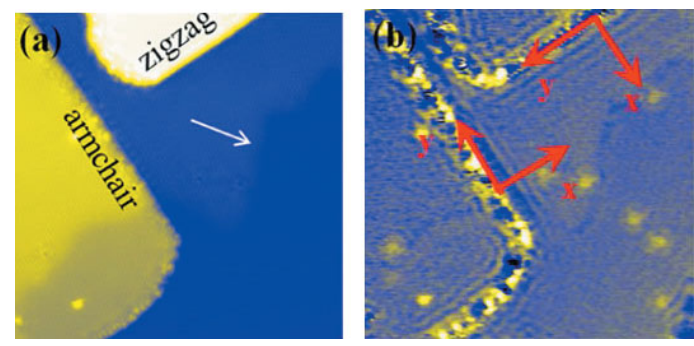

Fig. 4. (color online). (a) STM image and (b) dI/dV map of zigzag and armchair edges. See the details in Ref. 21), from which these figures are taken.

ア・エッジの波動関数はエッジに局在しないので, エッ ジに状態密度のピークは現れない。ところが, シリセン ではトポロジカル絶縁体なので, エッジの形によらず, ヘリカルエッジ状態が存在し, エッジにピークが現れ る ${ }^{20)}$ 。STM の局所状態密度の実験で, ジグザグとアー ムチェア・エッジともに状態密度のピークが観測され た 21)（Fig. 4)。まさに, シリセンがトポロジカル絶縁体 である最初の証拠だと著者は喜んでいたが，表面科学の 専門家の意見によると, 金属表面との吸着構造など他の 影響でもこのような状態密度が出ることがあるので，銀 盤上のシリセンがトポロジカル絶縁体であると決めるの はまだ早計のようで今後の進展が待ち遠しい。

シリセン・ナノディスクのエッジ状態：実際のサンプ ルはナノリボンのように無限に長いわけではなく, 閉じ た境界を持つ有限のサンプルである。このようなシリセ ン・ナノデイスクのエッジ状態を調べることは大変興味 深い。特に興味があるのはラフな境界を持つ系のエッジ 状態である。ラフな境界はジグザグとアームチェアが交 互に現れている境界と見なせる。このような系を数值的 に解析して, エッジ流が迁回しながら存在し続けること がわかった（Fig. 5)。これは, エッジ状態の存在がトポ ロジカルに保護されているので起こっている, と解釈で きる。

銀基板上のシリセンにディラック電子は存在している のか：現在のシリセンの実験に関しては, 銀基板上のシ リセンにディラック電子は存在しているのかという問題 が重要である。前述したように，自立したシリセンの低 エネルギー状態がディラック理論で記述されることは数 多くの第一原理計算で確認されており, 疑問の余地がな い。一方，現状では，シリセンは基板上にしか合成され ていないので，基板上でディラック電子が存在している のかが重要になる。ジルコニウム上では ARPES の結果 からもディラック電子がいるようには思えない。現在の シリセン・ブームの火付け役となった Guy Le Lay グル (a)

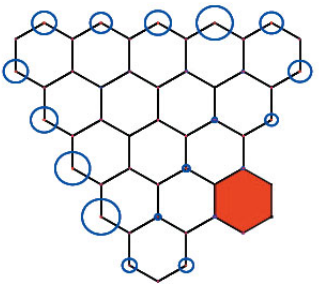

(b)

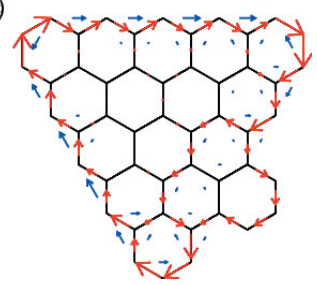

Fig. 5. (color online). (a) Wave function of silicene nanodisk. (b) Current flows of silicene nanodisk. See the details in Refs. 22), from which these figures are taken.

Table 1. Correspondence between the superstructure of silicene and the structure of silver substrate. Indeces $\mathrm{p}$ and $\mathrm{q}$ specifies the superstructure of silicene.

\begin{tabular}{ccccc}
\hline Si-superstructure & Ag-structure & $\mathrm{p}$ & $\mathrm{q}$ & ratio \\
\hline $3 \times 3$ & $4 \times 4$ & 3 & 0 & 1.33 \\
$2 \times 2$ & $\sqrt{7} \times \sqrt{7}$ & 2 & 0 & 1.32 \\
$\sqrt{7} \times \sqrt{7}$ & $\sqrt{13} \times \sqrt{13}$ & 2 & 1 & 1.36 \\
$2 \sqrt{3} \times 2 \sqrt{3}$ & $\sqrt{21} \times \sqrt{21}$ & 2 & 2 & 1.32 \\
$\sqrt{7} \times \sqrt{7}$ & $2 \sqrt{3} \times 2 \sqrt{3}$ & 2 & 1 & 1.31 \\
\hline
\end{tabular}

ープの実験結果では ARPES によって，分散を測定した ところ，線形分散が見えている。最近の実験ではさらに 綺麗な線形分散が見えている ${ }^{23)}$ 。しかし，実は $\mathrm{Ag}(111)$ の表面状態を観測しているのではないか，という見方も あり，注意が必要である。

一方，第一原理計算で銀基板上のシリセンの電子状態 が東大の押山グループらによって，計算されてい る ${ }^{24,25)}$ 。銀基板とシリセンの混合はかなり強く，ディラ ック電子はフェルミ面上には存在していない。

また，ランダウ準位を調べて，銀基板上のシリセンに 自由電子がいるのかを確かめた穾験も報告されてい る ${ }^{26)}$ 。グラフェンの場合には磁場をかけて, 状態密度を 測定するとランダウ準位に起因するシャープなピークが 観測される。同様の実験をシリセンで行ったところ, 7 テスラの磁場をかけても明確なピークが観測されなかっ た（Fig. 6)。これはシリセンには自由電子がないことを 示唆している。しかし，サンプルの大きさが十分でない 可能性や不純物の影響もあるかもしれないので，さらに 精度の良い実験があると望ましい。さらに，ディラック 電子特有の $\mathrm{V}$ 字型の状態密度が現れているのも興味深 い。

また準粒子干渉を用いた穾験から線形分散が見えたと

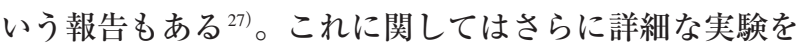
行うと実際には線形からのずれがあるという報告もなさ れている ${ }^{28)}$

このように，現状では，銀基板上のシリセンにディラ 
(a)
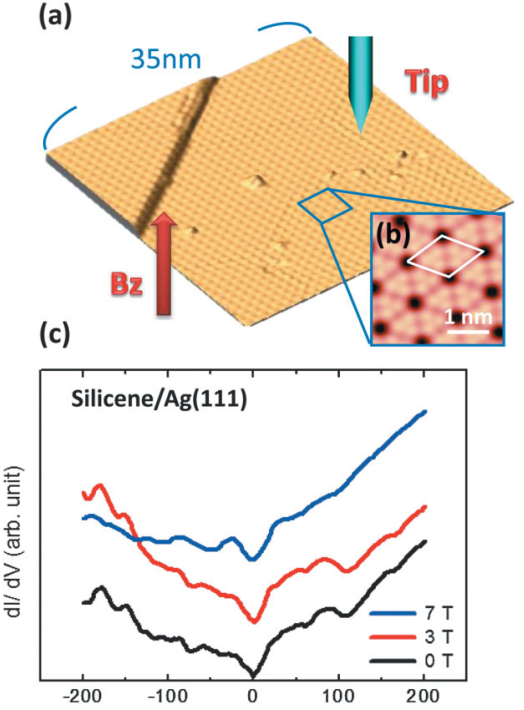

Fig. 6. (color online). (a) and (b) STM image and (b) DOS in silicene on Ag substarate. See the details in Refs. 26), from which these figures are taken.

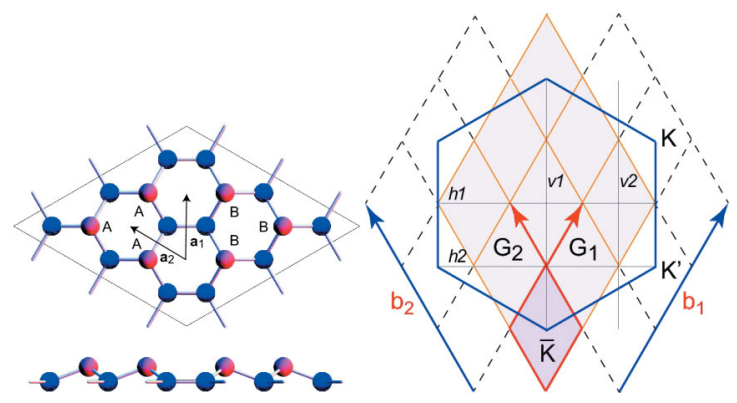

Fig. 7. (color online). Illustrations of silicene superstructure and the Brillouin zone of silicene superstructure. See the details in Refs. 29), from which these figures are taken.

ック電子はいるのかに関しては双方の実験が存在し, 議 論の余地がある。いずれにせよ，他の基板でシリセンを 合成することは重要である。

シリセンの超構造 : 基板の上にシリセンを合成すると 自立した場合とは違った構造になる。一般的に周期が自 立シリセンより長くなり，超構造を構成する。銀基板上 で一般的な構造を Fig. 7 に示す。単位胞に 18 個のシリ コンがあるので, Brilloin ゾーンは 1/9に折りたたまれ る。この結果, $\mathrm{K}$ 点と $\mathrm{K}^{\prime}$ 点が同一の場所に来てしまい, 自立したシリセンとは異なるトポロジカルな性質を持 つ。

一般的に基板上でどのような超構造が可能かを分類す ることが可能である ${ }^{29}$ 。超格子を生成するべクトルを $\mathbf{g}_{1}=p \mathbf{a}_{1}+q \mathbf{a}_{2}$ とすると, シリセンの単位胞の数は $N=$ $2\left|\mathbf{g}_{1}\right|=2 \sqrt{p^{2}+q^{2}+p q}$ で与えられる。一般的に $p \geq q$ を満 たす超構造が可能である。Table 1 に銀基板上のシリ七 ンでの典型的な超構造をまとめる。超構造の比がだいた い 1.3 であることは興味深い。根拠ははっきりとしない が，合成の際の基盤選びの指針になると思う。

\section{2 シリセンの合成}

絶縁体上にシリセンを合成できるか：現在は銀, $\mathrm{ZrB} 2$ ，イリジウムの三つの基板上でシリセンが合成さ れている。しかし，この三つの基板はどれも金属であ る。電気伝導度などを測定するためには, 基板が絶縁体 でないと都合が悪い。また, 将来的にシリセンを用いて デバイスを作製するためにも絶縁体上にシリセンを合成 することは大変重要である。これに関して, hexagonal Boron Nitride 基板上や水素終端したシリコンの 111 面上 にシリセンを成長させるとフェルミ面上にディラック・ コーンが出現するという理論提案がなされている ${ }^{24,25) 。}$ また, グラフェンの上のシリセンでもディラック・コー ンが存在することが第一原理計算で示された ${ }^{30)}$ 。実験的 にはどの基板を用いるかというのがキーポイントであ る。まず，表面の対称性は六回対称性か三回対称性であ ることが望ましい。このため, 111 面を使うのが適切で ある場合が多い。次に重要なのが，シリセンの格子間隔 と基板の格子間隔の比である。これは決定的なことは言 えないが，一般的には簡単な比になっていると格子整合 が良いことが期待できる。是非とも実験家にはいろいろ な基板を試して頂きたい。

磁性体上にシリセンを合成できるか：磁場をかけると 横方向に電流が流れる現象をホール効果という。十分低 温ではホール伝導度が量子化されて量子ホール効果が発 現する。磁場をかけなくても磁性体を貼り付けるとホー ル効果が起きることが知られていて異常ホール効果と呼 ばれている。これも十分低温では量子化し, 量子異常ホ 一ル効果となる。シリセンでも磁性体を貼り付けると量 子異常ホール効果が起きると考元られる ${ }^{311}$ 。鉄, マンガ ン, ニッケルなどの上でシリセンが合成できると大変面 白い。

超伝導体上にシリセンを合成できるか：前述したよう にシリセンは量子スピンホール効果を示すことが理論的 に示されている。一方, 量子スピンホール効果状態に超 伝導体を近接させると色々面白い現象が期待できる。た とえば, 試料の端に出るへリカル・エッジ状態に超伝導 を近接効果で導入するとマヨラナ粒子が発現する。ま た, 超伝導を近接させると量子スピンホール絶縁体から 自明な絶縁体へギャップを閉じずに相転移できるなど面 白い現象もある ${ }^{32}$ 。実は既にイリジウム基板上でシリセ ンの合成に成功しているが，イリジウムは $0.1 \mathrm{~K} て ゙$ 超伝 
導になる。イリジウム基板上のシリセンを低温にすると 何か面白いことが起きるかもしれない。

自立したシリセンを作製できるか：基板上にシリセン を合成すると基板の影響を多かれ少なかれ受けてしま う。究極的にはシリセンを自立 (free standing) した状 態にするのが理想的である。グラフェンの場合には実 際, サンプルを自立させることができ, 大変美しい実験 データが得られている。できるだけ基板との相互作用の 小さい基板上にシリセンを作製し，引きはがすのが理想 的である。他の方法としては, 基板上にシリセンを合成 してから，基板のみを溶かすという方法も考えられる。

3.3 ゲルマネン, スタネン, $\cdots$

グラフェンが炭素のハニカム格子で, シリセンがシリ コンのハニカム格子なのだから, 同様に, ゲルマニウム やスズ，鉛でも八ニカム格子を組むことができるのでは ないかと考えるは自然である。実際にそれらについて第 一原理計算で計算がされており, 構造安定であり, 低工 ネルギー励起はディラック理論で記述される ${ }^{13)}$ 。以下の 表に第一原理計算で求めた值を掲載する ${ }^{14)}$ 。理論的には ゲルマネン (germanene) やスタネン (stanene ${ }^{33}$ もシリ センと同じ八ミルトニアンで記述され, パラメータを入 れ替えるだけで良い。パラメー夕を Table 2 に示す。

この表を見るとゲルマネンのスピン軌道相互作用がと ても大きいことがわかる。室温でも量子スピンホール効 果を示すことが期待できる。実験的には, ゲルマネンも スタネンも合成されていない。これらの合成は表面科学 として大変チャレンジングである。問題は基板に何を使 うかである。シリセンよりも格子間隔が大きい, 銀より 重い元素の基盤を使うと良いかもしれない。

\section{4 二層シリセン・多層シリセン}

グラフェンでは二層, 三層のサンプルを作成すること ができ, バンド構造が変化するなど大変興味深い性質が ある。シリセンでも銀基板上で，二層のシリセンが作成 されている。二層シリセンの電気的性質も興味深い ${ }^{34)}$ 。 二層グラフェンの場合には面間結合が弱いが, 二層シリ センの場合はむしろ面間結合の方が面内結合よりも強い という第一原理計算の結果がある。これはシリセンでは

Table 2. Material parameters of grapheme, silicene and germanene. Transfer energy, Fermi velocity, lattice constant, spin-orbit interaction, Rashba interaction, layer distance and buckled angle.

\begin{tabular}{lccccccc}
\hline & $\begin{array}{c}t \\
(\mathrm{eV})\end{array}$ & $\begin{array}{c}\nu_{\mathrm{F}} \\
\left(10^{5} \mathrm{~m} / \mathrm{s}\right)\end{array}$ & $\begin{array}{c}a \\
(\AA)\end{array}$ & $\begin{array}{c}\lambda_{\mathrm{SO}} \\
(\mathrm{meV})\end{array}$ & $\lambda_{\mathrm{R} 2}$ & $\ell$ & $\theta$ \\
\hline Graphene & 2.8 & 9.8 & 2.46 & $10^{-3}$ & 0 & 0 & 90 \\
Silicene & 1.6 & 5.5 & 3.86 & 3.9 & 0.7 & 0.23 & 101.7 \\
Germanene & 1.3 & 4.6 & 4.02 & 43 & 10.7 & 0.33 & 106.5 \\
\hline
\end{tabular}

$\mathrm{sp}^{3}$ 軌道の混成があり, ダイヤモンド格子に近い性質を 持っていることと関係していると思われる。二層シリセ ンの ARPES でもディラック分散が見えたという実験の 報告がある ${ }^{35)}$ 。

さらに三層以上の多層シリセンも面白い。実験的には 多層シリセンはかなりの枚数まで積層できるようであ る。電気的性質に枚数依存性が表れるか等, 興味は尽き ない。一般的に銀基板の影響は枚数が増えるほど，すく なくなると期待される。

\section{5 シリセンで高温超伝導?}

シリセンではなんと $40 \mathrm{~K}$ の超伝導が出るという実験

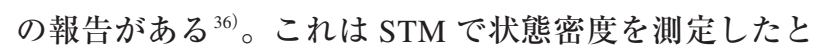
ころ，ギャップが開いており，40Kを超えたところで ギャップが消失したという実験である。色々追試が試み られているが，まだ追試に成功したという報告はない。 本当に超伝導ギャップなのか等の疑問が現在の時点では 残っているが, 本当であればシリセンで高温超伝導が実 現していることになり, 画期的な成果である。ちなみ に, 理論でも $10 \mathrm{~K}$ の BCS 超伝導が起きるという計算も ある ${ }^{37)}$ 。また, 二層シリセンでは $\mathrm{d}+\mathrm{id}$ 波の超伝導が出 るという予言もある ${ }^{38)}$ このようにシリセンは超伝導の 観点からも大変面白い現象が期待できる。

\section{6 シリセンで強相関電子系?}

グラフェンは電子間相互作用が小さい系である。これ は炭素が軽元素であるためである。シリコンは炭素より は重たいので, シリセンの電子間相互作用はグラフェン よりは強いと思われる。しかし, シリセンの電子間相互 作用についてはまだ，ほとんどわかっていない。たとえ ば遮蔽効果がどれぐらいなのか, というのは興味深い。 グラフェンでは遮蔽効果がほとんどないことが知られて いる。シリセンはグラフェンよりは遮蔽効果が強いと思 われるが, 定量的な解析が望まれる。グラフェンでは電 子間相互作用によって, 自発的にギャップが開き, ホー ル効果が起きる「自発的ホール効果」が提案されたが, クーロン相互作用が臨界点よりわずかに小さく, 実際に は実現しない。シリセンではこの「自発的ホール効果」 が起きる可能性がある。さらに, 相互作用が強く遮蔽も 強いなら, Kane-Mele-Hubbard 模型で記述されることに なり, トポロジカル・モット絶縁体が実現する可能性も ある。通常のシリコンは電子間相互作用のない半導体で よく記述されることが知られているので, シリセンが強 相関電子系である可能性は高くない。いずれにせよ， シ リセンの電子間相互作用についての研究はまだなく, 今 後の進展が望まれる。

3. 7 シリセンでトポロジカル・デバイス?

シリセンに電場をかけるとバンドギャップが制御でき 
ることを前述した。電場は空間的変調させることができ るので，バンドギャップを空間的に自在に変化させるこ とができる。また，臨界電場付近で制御できれば，トポ ロジカル相転移を空間分解で害現できる。つまり，ある 特定の領域だけをトポロジカル絶縁体にすることがで き，エッジ状態を発生させることが可能である ${ }^{17) 。 ~}$

また，エッジ状態を用いたトポロジカル・デバイスも 考えることができる。トポロジカル相ではエッジ状態が あり,ナノリボンを作成すると量子化した伝導度を持 つ。一方, 自明な相ではエッジ状態はないので, 伝導度 はゼロである。よって, 電場によるトポロジカル相転移 にともなって伝導度を制御できる ${ }^{39)}$ （Fig. 8)。トポロジ カルなエッジ状態は不純物などに対してロバストなの で，微細化したときに有効である。以上の性質から電界 誘起トポロジカル量子トランジスターと名付けるのが適 当である。

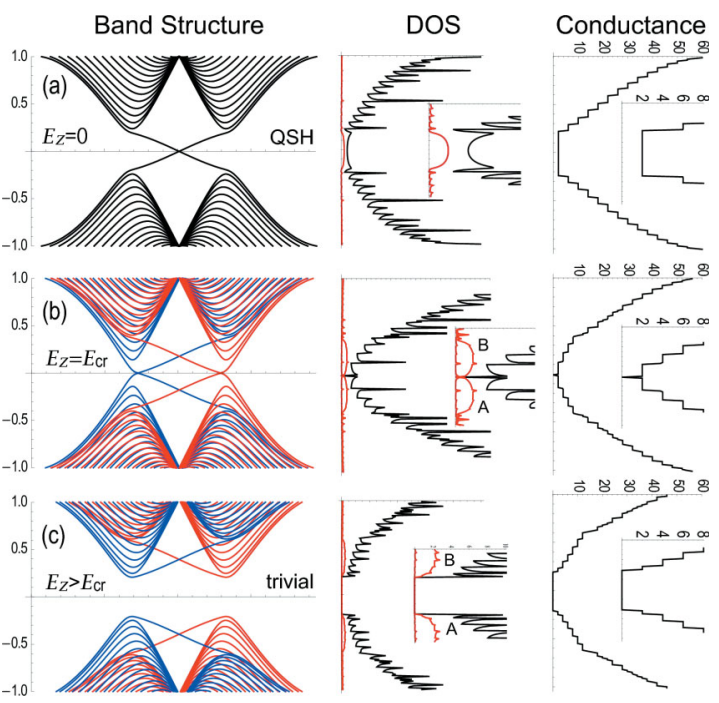

Fig. 8. (color online). Band structure, DOS and conductance of zigzag silicene nanoribbons for (a) the QSH insulator phase, (b) the metalic phase at the phase transition point, and (c) the trivial insulator. See the details in Refs. 39), from which these figures are taken.
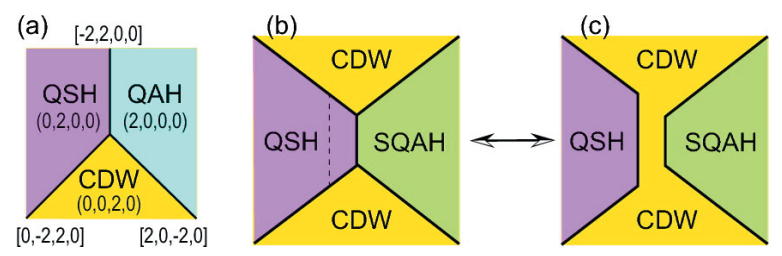

Fig. 9. (color online). (a) Illustration of topological Krichhoff law. (b) and (c) Topological electronic circuit made of topological edge states.
さらに，三種類のトポロジカル絶縁体を持ってくると トポロジカル・エッジ状態を用いて Y-junction を作成す ることができる ${ }^{40)}$ (Fig. 9)。それぞれのエッジ状態が持 つトポロジカル量子数を隣接する二つのトポロジカル絶 縁体の量子数の差で定義する。接合の場所ではこれらの 和は保存する。これは接合系の電流に対する保存則であ る Kirchhoff 則にならってトポロジカル Kirchhoff 則と呼 ぶべきものである。

\section{4. と め}

シリセンに関して現状と今後の課題について思いつく 限り纏めた。シリセンに関しては 2012 年の実験の報告 以来, 研究が急速に進展している。今後の進展が楽しみ な分野である。特に新規に参入する研究者が増えてくれ れば，この上ない喜びである。最後に色々ご議論・ご指 導して下さった永長直人先生, 青木秀夫先生, 内田慎一 先生, 安藤恒也先生, 勝本信吾先生, Guy Le Lay 先生, 長谷川修司先生, 高木紀明先生, 高村由起子先生, 平山 博之先生, 小森文夫先生, 斎藤晋先生, 押山淳先生, 白 石賢二先生, 上田正仁先生, 田仲由喜夫先生, 平原徹先 生に感謝致します。

\section{文献}

1) 江澤雅彦: 固体物理 48, 4 (2013).

2) 高村 (山田) 由起子, アントワーヌ・フロランス, ラ イナー・フリードライン, 尾崎泰助: 日本物理学会 誌 68, 305 (2013).

3) 固体物理 特集号: デイラック電子系の固体物理 No. 11 (2010).

4) 表面科学 特集: トポロジカル絶縁体, 173 (2011).

5) 初貝安弘, 青木秀夫 : 固体物理 No. 9, 457 (2010).

6) 村上修一: 固体物理 No. 9, 477 (2010).

7) 村上修一, 平原 徹, 松田 嚴: 日本物理学会誌 $\mathbf{6 5}$, 840 (2010).

8) K. Takeda and K. Shiraishi : Phys. Rev. B 5014916 (1994).

9) P. Vogt, P. De Padova, C. Quaresima, J. Avila, E. Frantzeskakis, M.C. Asensio, A. Resta, B. Ealet and G.L. Lay : Phys. Rev. Lett. 108, 155501 (2012).

10) C.-L. Lin, R. Arafune, K. Kawahara, N. Tsukahara, E. Minamitani, Y. Kim, N. Takagi and M. Kawai : Appl. Phys. Express 5, 045802 (2012).

11) A. Fleurence, R. Friedlein, T. Ozaki, H. Kawai, Y. Wang and Y. Yamada-Takamura : Phys. Rev. Lett. 108, 245501 (2012).

12) L. Meng, Y. Wang, L. Zhang, S. Du, R. Wu, L. Li, Y. Zhang, G. Li, H. Zhou, W.A. Hofer and H.-J. Gao : Nano Lett. 13, 685 (2013).

13) C.-C. Liu, W. Feng and Y. Yao : Phys. Rev. Lett. 107, 076802 (2011).

14) C.-C. Liu, H. Jiang and Y. Yao : Phys. Rev. B, 84, 
195430 (2011).

15) H. Min, J.E. Hill, N.A. Sinitsyn, B.R. Sahu, L. Kleinman and A.H. MacDonald: Phys. Rev. B 74, 165310 (2006).

16) Y. Yao, F. Ye, X.-L. Qi, S.-C. Zhang and Z. Fang : Phys. Rev. B 75, 041401 (R) (2007).

17) M. Ezawa : New J. Phys. 14, 033003 (2012).

18) M. Ezawa : Phys. Rev. Lett. 110, 026603 (2013).

19) M. Ezawa : Phys. Rev. B 87, 155415 (2013).

20) M. Ezawa and N. Nagaosa : Phys. Rev. B 88, 121401 (R) (2013).

21) B. Feng, H. Li, C.-C. Liu, T. Shao, P. Cheng, Y. Yao, S. Meng, L. Chen and K. Wu : ACS Nano 7, 9049 (2013).

22) K. Kikutake, M. Ezawa and N. Nagaosa : Phys. Rev. B 88, 115432 (2013).

23) J. Avila, P. De Padova, S. Cho, I. Colambo, S. Lorcy, C. Quaresima, P. Vogt, A. Resta, G. Le Lay and M.C. Asensio: J. Phys. : Condens. Matter 25262001 (2013).

24) Z.-X. Guo, S. Furuya, J. Iwata, A. Oshiyama : J. Phys. Soc. Jpn. 82, 063714 (2013).

25) Z.-X. Guo, S. Furuya, J. Iwata, A. Oshiyama : Phys. Rev. B 87, 235435 (2013).

26) C.-L. Lin, R. Arafune, K. Kawahara, M. Kanno, N. Tsukahara, E. Minamitani, Y. Kim, M. Kawai and N. Takagi : Phys. Rev. Lett. 110, 076801 (2013).

27) L. Chen, C.-C. Liu, B. Feng, X. He, P. Cheng, Z. Ding, S. Meng, Y. Yao and K. Wu : Phys. Rev. Lett. 109, 056804
(2012).

28) R. Arafune, C.-L. Lin, R. Nagao, M. Kawai and N. Takagi : Phys. Rev. Lett. 110, 229701 (2013).

29) M. Ezawa : Eur. Phys. J. B 86, 139 (2013).

30) Y. Cai, C.-P. Chuu, C.M. Wei and M.Y. Chou : Phys. Rev. B 88, 245408 (2013).

31) M. Ezawa : Phys. Rev. Lett. 109, 055502 (2012).

32) M. Ezawa, Y. Tanaka and N. Nagaosa : Sci. Rep. 3, 2790 (2013).

33) Y. Xu, B. Yan, H. -J. Zhang, J. Wang, G. Xu, P. Tang, W. Duan and S.-C. Zhang: Phys. Rev. Lett. 111, 136804 (2013).

34) M. Ezawa : J. Phys. Soc. Jpn. 81, 104713 (2012).

35) P. De Padova, P. Vogt, A. Resta, J. Avila, I. RazadoColambo, C. Quaresima, C. Ottaviani1, B. Olivieri, T. Bruhn, T. Hirahara, T. Shirai, S. Hasegawa, M.C. Asensio and G.L. Lay : Appl. Phys. Lett. 102, 163106 (2013).

36) L. Chen, B. Feng and K. Wu : Appl. Phys. Lett. 102, 081602 (2013).

37) W. Wan, Y. Ge, F. Yang and Y. Yao : EPL, 104, 36001 (2013).

38) F. Liu, C.-C. Liu, K. Wu, F. Yang and Y. Yao: Phys. Rev. Lett. 111, 066804 (2013).

39) M. Ezawa : Appl. Phys. Lett. 102, 172103 (2013).

40) M. Ezawa : Phys. Rev. B 88, 161406 (R) (2013). 